BIOMEDICAL AND BIOSOCIAL ANTHROPOLOGY
$\begin{gathered}\text { Official Journal of the International Academy } \\ \text { of Integrative Anthropology } \\ \text { journal homepage: http://bba-journal.com }\end{gathered}$

\title{
Features of changes of the functional state of higher nervous activity of the students of higher educational medical institutions in the dynamics of the academic year
}

Moroz V. M., Makarov S. Yu.

National Pirogov Memorial Medical University, Vinnytsya, Ukraine

\section{ARTICLE INFO}

Received: 29 March, 2018

Accepted: 27 April, 2018

UDC: $159.923 .31+612.821$ :

378.145 .3

\section{CORRESPONDING AUTHOR}

e-mail: admission@vnmu.edu.ua Moroz V. M.

\begin{abstract}
In the structure of the most important components to ensure the optimal course of processes of psychophysiological adaptation of student's youth, a special place occupies a degree of psychophysiological readiness of the organism to effectively mastering professionally meaningful skills and actions. The purpose of the study is to determine the peculiarities of changes in the leading indicators of the functional state of higher nervous activity of students of medical institutions of higher education in the dynamics of the academic year. Determination of the level of development of indicators of the functional state of higher nervous activity of students was conducted during the academic year with the use of the licensed computer complex "Efecton Studio". Statistical processing of the received materials was carried out on the basis of the use of parametric methods using the program package of multidimensional statistical analysis "Statistica 6.1". The obtained results confirm the presence of certain regularities. First, attention should be paid to the deterioration during the period of stay in institutions of higher education in the medical profile of the expression of such indicators of the functional state of higher nervous activity as the speed of simple and differentiated visual-motor reactions and the balance of nervous processes. Secondly, it is necessary to determine stable results in the dynamics of the academic year, which are characteristic of the indicators of mobility of the nervous processes. Thirdly, it should be emphasized that for indicators of speed of audio-motor reaction the most typical tendency is gradual improvement in the dynamics of time of stay in medical institutions of higher education. Such a variety of palettes of the studied indicators of the degree of development of the leading indicators of the functional state of higher nervous activity of the body of students requires to be taken into account when assessing the psychophysiological status of the subjects and the development of a set of diagnostic means for identifying the processes of forming the functional capabilities and adaptive resources of youth, who receive medical education.
\end{abstract}

Keywords: students, medical institutions of higher education, higher nervous activity, functional state, changes in the dynamics of the academic year.

\section{Introduction}

In the structure of the most important components of ensuring the optimal, based on physiological positions, and successful, taking into account the educational and pedagogical aspects of the problem, the course of psychophysiological adaptation processes, effective professional formation and adequate professional-oriented training in the institution of higher education, a special place, undeniably, occupies a degree of psychophysiological readiness of an organism of student youth for the effective assimilation of professionally meaningful techniques, skills, actions and operations and, accordingly, adequate formation of a working dynamic stereotype, which is an integral and obligatory component of adequate professional training [2, 4, 5, 8-11, 15-17, 21, 27-29, 32]. This situation determines the urgent need for in-depth research, in the center of which there are questions aimed at carrying out a comprehensive in-depth assessment of changes on the basis of the peculiarities of psychophysiological functions of students during the time of stay in the institution of higher education, especially in 
the dynamics of the academic year, and mark the physiological reactions of the youth organism in response to the action of day-to-day learning (a constant component of educational stress) $[1,6,7,12-14,18-20,22,24,26,30$, 31].

The purpose of the work is to determine the peculiarities of changes in the leading indicators of the functional state of higher nervous activity of students of medical institutions of higher education in the dynamics of the academic year.

\section{Materials and methods}

The research was conducted among students (30 young women and 30 young men) of the medical faculty of National Pirogov Memorial Medical University, Vinnytsya.

Determination of the level of development of indicators of the functional state of higher nervous activity of students and, above all, indicators that determine the features of sensorimotor reactions (the speed of simple and differentiated visual-motor response, simple audio-motor reaction), the course of the main nervous processes (mobility and balance of nerve processes) was carried out during the academic year (accordingly, at the beginning of the autumn and at the end of spring semester) with the use of a specially created for these purposes, a licensed computer complex "Effecton Studio", which has a certificate of compliance with the Institute of Information Education and registered in the Fund of Computer Programs of Educational Purposes (Reg. No. 1717) [16].

For the statistical processing of the received materials, a standard package of applied programs of multivariate statistical analysis "Statistica 6.1" (license number BXXR901E245722FA, belonging to the National Pirogov Memorial Medical University, Vinnytsya) was used [3, 23].

\section{Results}

The results of the conducted researches, which envisaged the identification of the main features of the shifts recorded by the indicators of the functional state of higher nervous activity of students of medical institutions of higher education during the academic year, indicate the existence of a number of interesting patterns of the identified changes, which are given in Table 1.

\section{Discussion}

The initial stage of determining the level of psychophysiological readiness of students to successfully mastering the learning material and mastering practical skills is considered to be a comprehensive assessment of the peculiarities of the development of indicators of the functional state of higher nervous activity. First of all, it concerns its high-speed characteristics, above all simple visual-motor reaction, the indicators of which provide an opportunity to fully adequately determine the degree of formation of indicators of visual-motor coordination capabilities, which are at the basis of ensuring the adequate implementation of various socio-and
Table 1. Indicators of the leading characteristics of the higher nervous activity of students in the dynamics of the academic year in a medical institution of higher education.

\begin{tabular}{|c|c|c|c|c|c|c|}
\hline \multirow{2}{*}{ Indexes } & \multirow{2}{*}{$\begin{array}{c}\text { Study } \\
\text { period }\end{array}$} & \multicolumn{2}{|c|}{ Young women } & \multicolumn{2}{|r|}{ Young men } & \multirow{2}{*}{$p(t)_{w-m}$} \\
\hline & & $n$ & $\mathrm{M} \pm \mathrm{m}$ & $n$ & $\mathrm{M} \pm \mathrm{m}$ & \\
\hline \multirow{3}{*}{$\begin{array}{l}\text { Latent period } \\
\text { of simple } \\
\text { visual-motor } \\
\text { reaction, ms }\end{array}$} & Start & 30 & $336.5 \pm 4.8$ & 30 & $331.6 \pm 5.8$ & $>0.05$ \\
\hline & finish & 30 & $361.4 \pm 6.7$ & 30 & $360.5 \pm 8.6$ & $>0.05$ \\
\hline & $p(t)_{s-f}$ & \multicolumn{2}{|c|}{$<0.01$} & \multicolumn{2}{|c|}{$<0.01$} & \\
\hline \multirow{3}{*}{$\begin{array}{l}\text { Latent period } \\
\text { of } \\
\text { differentiated } \\
\text { visual-motor } \\
\text { reaction, ms }\end{array}$} & Start & 30 & $429.1 \pm 9.3$ & 30 & $424.7 \pm 6.8$ & $>0.05$ \\
\hline & finish & 30 & $463.7 \pm 9.3$ & 30 & $465.4 \pm 10.8$ & $>0.05$ \\
\hline & $p(t)_{s-f}$ & \multicolumn{2}{|c|}{$<0.05$} & \multicolumn{2}{|c|}{$<0.01$} & \\
\hline \multirow{3}{*}{$\begin{array}{l}\text { Mobility of } \\
\text { nerve } \\
\text { processes, } \\
\text { number of } \\
\text { failures of } \\
\text { differentiated } \\
\text { reactions }\end{array}$} & Start & 30 & $1.066 \pm 0.165$ & 30 & $0.933 \pm 0.197$ & $>0.05$ \\
\hline & finish & 30 & $1.166 \pm 0.173$ & 30 & $1.066 \pm 0.197$ & $>0.05$ \\
\hline & $p(t)_{s-f}$ & \multicolumn{2}{|c|}{$>0.05$} & \multicolumn{2}{|c|}{$>0.05$} & \\
\hline \multirow{3}{*}{$\begin{array}{c}\text { Steadiness of } \\
\text { nerve } \\
\text { processes, } \\
\text { error in ms }\end{array}$} & Start & 30 & $43.73 \pm 2.65$ & 30 & $46.43 \pm 2.83$ & $>0.05$ \\
\hline & finish & 30 & $56.56 \pm 3.61$ & 30 & $57.96 \pm 2.87$ & $>0.05$ \\
\hline & $p(t)_{s-f}$ & \multicolumn{2}{|c|}{$<0.01$} & \multicolumn{2}{|c|}{$<0.01$} & \\
\hline \multirow{3}{*}{$\begin{array}{l}\text { Latent period } \\
\text { of a simple } \\
\text { audio-motor } \\
\text { reaction, ms }\end{array}$} & Start & 30 & $298.4 \pm 10.7$ & 30 & $292.4 \pm 9.4$ & $>0.05$ \\
\hline & finish & 30 & $266.6 \pm 5.2$ & 30 & $265.3 \pm 6.6$ & $>0.05$ \\
\hline & $p(t)_{s-f}$ & \multicolumn{2}{|c|}{$<0.01$} & \multicolumn{2}{|c|}{$<0.05$} & \\
\hline
\end{tabular}

professionally significant sensory-motor acts and, consequently, motor skills necessary for successful theoretical and practical activities in institutions of higher education of future medical professionals $[2,5,8,12,17$, $20,25,29,32]$.

The results pointed to the fact that among young men and women, the latent period of the simple visual-motor response at the beginning of the academic year was $336.5 \pm 4.8 \mathrm{~ms}$ and $331.6 \pm 5.8 \mathrm{~ms}$, respectively, at the end of it $361.4 \pm 6.7 \mathrm{~ms}\left(7.3 \% ; \mathrm{p}(\mathrm{t})_{\mathrm{s}-\mathrm{f}}<0.01\right)$ and $360.5 \pm 8.6 \mathrm{~ms}$ $\left(8.7 \% ; \mathrm{p}(\mathrm{t})_{\mathrm{s}-\mathrm{f}}<0.01\right)$ and, consequently, in both cases statistically significant deteriorated during the research period. At the same time, no reliable gender-related differences in the dynamics of training were observed $\left(p(t){ }_{w-}\right.$ $\mathrm{m}>0.05)$.

Similar in their leading content of the trend (gradual deterioration of the degree of expression of the studied characteristics) were characteristic of indicators of the functional state of higher nervous activity, which marked the peculiarities of the development of characteristics of the speed of differentiated visual-motor response, which provides information regarding the degree of effectiveness of the implementation of coordinated motor acts while performing stereotyped professionally meaningful actions, movements, techniques that are inextricably linked with the recognition of different content (positive, negative, indifferent) signals arriving to a person during their implementation. In particular, at the beginning of the academic year, in young men and women, the values of the latent period of the differentiated visually-motor reactions 


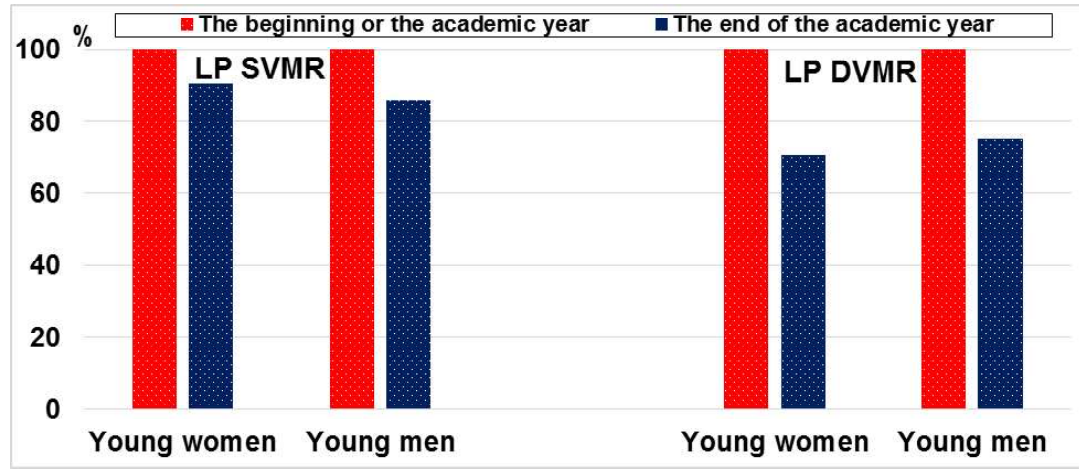

Fig. 2. Data of the comparative analysis of the peculiarities of development of indicators of mobility and equilibrium of the nervous processes of students who were researched in the dynamics of the academic year in a medical institution of higher education. MNP mobility of the nervous processes. BNP - balance of the nervous processes.

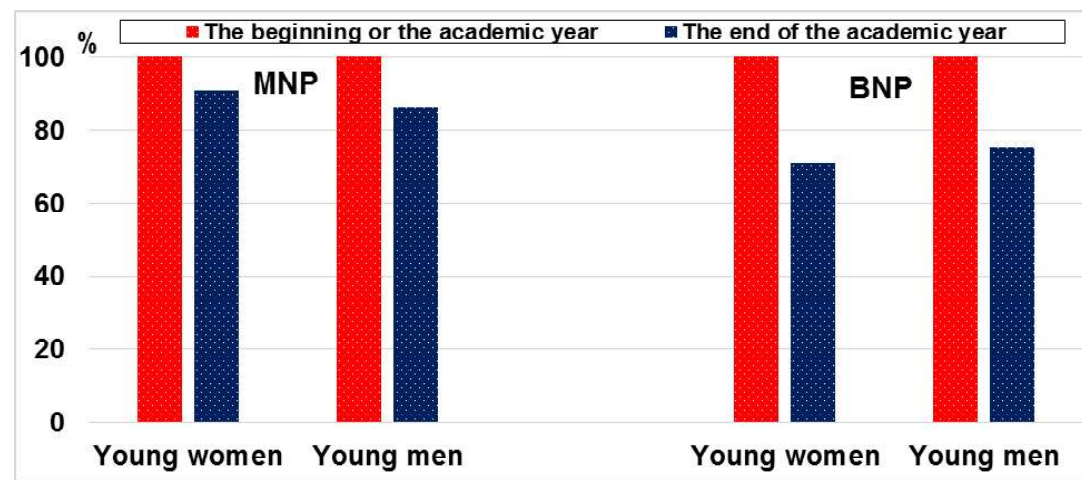

Fig. 1. Data of the comparative analysis of the peculiarities of the development of indicators of the speed of the simple and differentiated visual-motor reaction of students, who were researched in the dynamics of the academic year in a medical institution of higher education. LP SVMR - Latent period of simple visual-motor reaction. LP DVMR Latent period of differentiated visual-motor reaction.

respectively $429.1 \pm 9.3 \mathrm{~ms}$ and $424.7 \pm 6.8 \mathrm{~ms}$ respectively, at the end of it - respectively $463.7 \pm 9.3 \mathrm{~ms}(8.0 \%$; $\mathrm{p}(\mathrm{t}) \mathrm{s}$. $<0.05)$ and $465.4 \pm 10.8 \mathrm{~ms}\left(8.8 \% ; \mathrm{p}(\mathrm{t})_{\mathrm{s}-\mathrm{f}}<0.01\right)$. As in the previous case, there were no reliable gender-related differences in the study dynamics $\left(p(t)_{w-m}>0.05\right)$.

Fig. 1 shows the data of the comparative analysis of the peculiarities of the development of speed indicators of the simple and differentiated visual-motor reaction of students who were researched in the dynamics of the academic year in medical institutions of higher education.

Carrying out a comprehensive assessment of the indicators that determine the peculiarities of the mobility of the nerve processes, and thus allow to establish both patterns and peculiarities of the ratio of excitation and inhibition processes in the structure of higher nervous activity, providing clear and specific information on the processes of forming a working dynamic stereotype, which is the basis of an adequate and fully successful assimilation of typical motor activity in the performance of certain activities, including medical specialties, it should be noted that among young men and women the number of failures of differentiated reactions at the beginning of the school year was respectively $1.066 \pm 0.167$ and $0.933 \pm 0.197$, at the end of it - respectively $1.166 \pm 0.173$ $\left(9.4 \% ; p(t)_{s-f}>0.05\right)$ and $1.066 \pm 0.197$ $\left(13.9 \% ; p(t)_{s-f}>0.05\right)$ and, consequently, in a statistically significant degree deteriorated during the time of research in both cases. Instead, no reliable gender-related differences in the dynamics of education were observed $\left(p(t)_{w-m}>0.05\right)$.

Finally, summarizing data reflecting the peculiarities of dynamic changes during the academic year in medical institutions of higher education by the leading characteristics of the balance of nerve processes that determine the patterns of interconnection and interdependence of the main nervous processes, which are an important prerequisite for an adequate implementation of stereotypical actions in the imposed rhythm during the performance of educational activities, is a complex spatial-temporal reflex, which can be used to determine the level of relations between the processes of excitation and inhibition in the cerebral cortex. So, at the beginning of the academic year at the university, young men and women the error of determining the reaction to the moving object and, consequently, the degree of expression of the balance of the main nervous processes was $43.73 \pm 2.65 \mathrm{~ms}$ and $46.43 \pm 2.83 \mathrm{~ms}$, respectively, at the end of it - respectively, $56.56 \pm 3.61 \mathrm{~ms}\left(29.3 \% ; \mathrm{p}(\mathrm{t})_{\mathrm{s}-\mathrm{f}}<0.01\right)$ and $57.96 \pm 2.87 \mathrm{~ms}$ $\left(24.8 \% ; p(t)_{s-f}<0.01\right)$. As in all previous cases, no statistically significant gender-induced differences in the dynamics of training were observed $\left(\mathrm{p}(\mathrm{t})_{\mathrm{w}-\mathrm{m}}>0.05\right)$.

In Fig. 2 data on the comparative analysis of the peculiarities of the development of mobility indicators and equilibrium of the nervous processes of students who were researched in the dynamics of the academic year at the institution of higher education are presented.

Another important indicator of the complex assessment of the peculiarities of the development of indicators of the functional state of higher nervous activity should be considered determination of the degree of formation of criterion characteristics of audio-motor or auditory-motor coordination capabilities and, respectively, indicators of the latent period of audio-motor reaction, which are also at the basis of effective implementation of various socially- and professionally significant sensory-motor acts and, consequently, the various motor techniques necessary for a successful theorist and the practical activities of medical students [2, 7, 8, 10, 17, 22].

The data received were quite opposite in comparison 
with the previous contents, testifying that among young men and women the magnitude of the latent period of the audiomotor reaction in the beginning of the academic year was 298.4 $\pm 10.7 \mathrm{~ms}$ and $292.4 \pm 9.4 \mathrm{~ms}$ respectively, at the end of it - respectively $266.6 \pm 5.2 \mathrm{~ms}\left(10.7 \% ; \mathrm{p}(\mathrm{t})_{\mathrm{s}-\mathrm{f}}<0.01\right)$ and $265.3 \pm 6.6 \mathrm{~ms}\left(9.3 \% ; \mathrm{p}(\mathrm{t})_{\mathrm{s}-\mathrm{f}}<0.05\right)$, and in both cases, had statistically significant improvement during research period. At the same time, no reliable gender-related differences in the dynamics of education were observed $\left(p(t)_{w-m}>0.05\right)$.

Consequently, the results of a comprehensive assessment of changes by the leading features of the formation of indicators of the functional state of higher nervous activity of students of medical institutions of higher education, which are observed in the dynamics of the academic year, evidenced by a number of quite interesting laws that need to be noted, first of all. First, attention should be paid to the phenomena of the deterioration of the functional capabilities of the body of both young women and young men during the period of stay in institutions of higher education of the medical profile during the study period, concerning such indicators of the functional state of higher nervous activity as the speed of a simple and differentiated visual- motor reaction and the balance of nervous processes. Secondly, the attention is drawn to the rather stable results in the dynamics of the academic year, which are characteristic of the indicators of mobility of the nervous processes. Thirdly, it should be noted that for the indicators of speed of the audio-motor reaction, which were determined, the most typical tendency should be considered the gradual improvement in the dynamics of time of stay in medical institutions of higher education. Such a variety of palettes of the studied indicators of the degree of development of the leading indicators of the functional state of higher nervous activity of students requires to be taken into account when assessing the psycho-physiological status of the subjects and the development of a diagnostic complex (modern methods of determining the features of psychophysiological adaptation) and corrective (modern approaches to

\section{References}

[1] Aguado, L., Fernandez-Cahill, M., \& Roman, F. J. (2008). Evaluative and Psychophysiological Responses to Short Film Clips of Different Emotional Content. Journal of Psychophysiology, 32, 1-19. https://doi.org/10.1027/02698803/a000180

[2] Aleksandrov, Yu. I. (2004). Psychophysiology. Saint Petersburg: Piter.

[3] Antomonov, M. Yu. (2017). Mathematical processing and analysis of biomedical data. Kyiv: IIC "Medinform".

[4] Avdeyuk, O. A., Aseeva, E. N., \& Tarasova, I. A. (2011). The problem of adapting students to the conditions of the university and the assistance of the teacher in her decision. In the world of scientific discoveries, 4.1 (16), 405-409.

[5] Baranov, A. A., Kuchma, V. R., \& Suhareva, L. M. (2008). Medical and social aspects of adaptation of modern adolescents to conditions of education, training and labor activity. Moscow: GOETAR-Media.

[6] Bodrov, V. A. (2000). Information stress. Moscow: PERSE. overcoming the identified negative in its content of phenomena) means of determining the processes of forming the functional capabilities and adaptive resources of the body of young men and women who receive medical education. This approach is an important continuation of the work, the data presented in a series of studies devoted to the psycho-physiological aspects of providing day-today activities of student youth [8, 17, 20, 21, 25-28, 32]. The necessity of using such approaches is also emphasized by the lack of well-defined tendencies in the usual conditions of educational activity, the main content of which is the steady positive development of the indicators of the functional state of higher nervous activity that underlie the formation of the working dynamic stereotype necessary for successful assimilation by modern student youth necessary theoretical knowledge and abilities, as well as practical skills [2, 10, 13, 25-27, 29].

\section{Conclusion}

In the course of the conducted research the peculiarities of changes on the leading indicators of the functional state of higher nervous activity of students of medical institutions of higher education in the dynamics of the academic year are determined, which are marked by the presence of manifestations of their decadence (the speed of simple and differentiated visual-motor reaction and the balance of nerve processes) and improvement (speed of audio-motor reaction) level of their expression and stable indicators (mobility of nervous processes). Defined data are essential both in terms of determining the peculiarities of the formation of the adaptive resources of the body of young men and women who are studying in higher educational institutions of the medical profile, and from the point of view of establishing practical, meaningful approaches to the formation of the personality of students, ensuring the formation of the necessary for a successful mastering of the future specialty of the dynamic working stereotype of educational and professional activities.

[7] Bodrov, V. A. (2006). Psychology of professional activity. Theoretical and applied problems. Moscow: Publishing house "Institut psikhologii RAN".

[8] Buckman, J. F., Vaschillo E. G., Fonoberova M., Mezi? I., \& Bates, M. E. (2018). The Translational Value of Psychophysiology Methods and Mechanisms: Multilevel, Dynamic, Personalized. Journal of Studies on Alcohol and Drugs, 79(2), 229-238. https://doi.org/10.15288/ jsad.2018.79.229

[9] Hagger, M. S., \& Chatzisarantis, N. L. D. (2011). Causality orientations moderate the undermining effect of rewards on intrinsic motivation. Journal of Experimental Social Psychology, 47, 485-489. doi:10.1016/j.jesp.2010.10.010

[10] Il'in, E. P. (2005). Psychophysiology of human conditions. Saint Petersburg: Piter.

[11] Installation and use manual "Effective Studio" [Electronic resource]. Access mode: http://effecton.su/docs/manual.pdf.

[12] Kal'ny`sh, V. V., \& Shvecz`, A V. (2007). Psychophysiological 
features of the quality of the tasks at the increase of their complexity. Physiological journal, 53(5), 99-108.

[13] Kalnish, V. V. (2008). Psychophysiological aspects of studying the reliability of operator activity. Ukrainian Journal of Occupational Medicine Problems, 3(15), 81-88.

[14] Kumar Pandey, A. L. \& Pandey, B. (2017). Neurophysiology of Social Conduct and Impact of Adverse Exposures. Avicenna J. Neuro Psycho Physiology, 4(1): 1-8. doi: 10.5812/ ajnpp.12452

[15] Kundiev, Y. I., \& Nagornaya, A. M. (2007). Professional health in Ukraine. Epidemiological analysis. Kyiv: Avicenna.

[16] Litvinova, N. A., Kazin, E. M., Lur'e, S. B., \& Bulatova, O. V. (2011). The role of individual psychophysiological features in adaptation to mental activity. Herald of the Kemerovo State University, 1, 141-147.

[17] McAdams, D. P., \& Olson, B. D. (2010). Personality development: Continuity and change over the life course. Annual Review of Psychology, 61, 517-542. doi:10.1146/ annurev.psych.093008.100507

[18] Meares, R., Gerull, F., Stevenson, J., \& Korner, A. (2011). Is self disturbance the core of Borderline Personality Disorder? An outcome study of Borderline personality factors. Australian and New Zealand Journal of Psychiatry, 45, 214-222. doi:10.3109/00048674.2010.551280

[19] Meyer, B., Ajchenbrenner, M., \& Bowles, D. P. (2005). Sensory sensitivity, attachment experiences and rejection responses among adults with Borderline and avoidant features. Journal of Personality Disorders, 19(6), 641-658. doi:10.1521/ pedi.2005.19.6.641

[20] Moroz, V. M., \& Makarov, S. Y. (2017). Methodology of complex assessment of the level of expression of students' educational stress during the academic year and in the predeficial and exam period. Biomedical and biosocial anthropology, 29, 182189.

[21] Moroz, V. M., \& Makarov, S. Y. (2017). Mechanisms of psychological protection of modern students and their changes on the eve of examinations: psychophysiological aspects. Biomedical and biosocial anthropology, 28, 6-10.

[22] Raygorodskiy, D. Ya. (2011). Practical psychodiagnostics. Techniques and tests. Samara: Publishing House "BahrahM".
[23] Rebrova, O. Yu. (2006). Statistical analysis of medical data. Application of the Statistica software package. Moscow: MediaSphera.

[24] Schauer, M., Elbert, T. (2010). Dissociation following traumatic stress: Etiology and treatment. Journal of Psychology, 218(2), 109-127. doi:10.1027/0044-3409/a000018

[25] Serheta, I. V., Bratkova, O. Y., Mostova, O. P., Panchuk, O. Y., \& Dudarenko, O. B. (2012). Scientific principles of psychohygienic diagnostics of the health of children, adolescents and youth. Environment and health, 4(64), 2125.

[26] Serheta, I. V., Grigorchuk, L. I., \& Molchanova, O. P. (2002). Ways of optimization of professional adaptation of students to the conditions of study at a medical higher educational institution and their predictive value. Environment and health, 4(23), 57-61.

[27] Serheta, I. V., Panchuk, O. Y., Stoyan, N. V., Drezhenkova, I. L., \& Makarov, S. Y. (2016). University hygiene in the context of implementation of the "Law on Higher Education": physiological and hygienic bases, realities and ways of development. Environment and health, 4(80), 46-52.

[28] Sidorova, K. A., Sidorova, T. A., \& Dragich, T. A. (2012). Analysis of the characteristics of the psychophysiological indicators of the organism of students in the process of their education in the university. Basic research, 2-5, 426-430.

[29] Valsine, J. (2018). Needed in Psychology: Theoretical Precision. Europe's Journal of Psychology. 14(1), 1-6, doi:10.5964/ ejop.v14i1.1602

[30] Weber, K., Miller, G. A., Schupp, H.T., Borgelt, J., Awiszus, B., Popov, T., \& Rockstroh, B. (2009). Early life stress and psychiatric disorder modulate cortical responses to affective stimuli. Psychophysiology, 46, 1234-1243. doi:10.1111/j.14698986.2009.00871.x

[31] Welch, S. S., Linehan, M. M., Sylvers, P., Chittams, J., \& Rizvi, S. (2008). Emotional responses to self-injury imagery among adults with Borderline Personality Disorder. Journal of Consulting and Clinical Psychology, 76(1), 45-51. doi:10.1037/ 0022-006X.76.1.45

[32] Yakovlev, B. P., \& Litovchenko, O. G. (2008). Psychophysiological characteristics of the level of performance of students. Hygiene and Sanitation, 1, 60-63.

\section{ОСОБЛИВОСТІ ЗМІН 3 БОКУ ПОКАЗНИКІВ ФУНКЦІОНАЛЬНОГО СТАНУ ВИЩОЇ НЕРВОВОЇ ДІЯЛЬНОСТІ СТУДЕНТІВ МЕДИЧНИХ ЗАКЛАДІВ ВИЩОЇ ОСВІТИ В ДИНАМІЦІ НАВЧАЛЬНОГО РОКУ \\ Мороз В. М., Макаров С. Ю.}

У структурі найважливіших компонентів забезпечення оптимального перебігу процесів психофізіологічної адаптації студентської молоді особливе місце займає ступінь психофізіологічної готовності організму до ефективного засвоєння професійно-значущих навичок і дій. Метою дослідження є визначення особливостей змін з боку провідних показників функціонального стану вищої нервової діяльності студентів медичних закладів вищої освіти в динаміці навчального року. Визначення рівня розвитку показників функціонального стану вищої нервової діяльності студентів проводилось протягом навчального року із застосуванням ліцензованого комп'ютерного комплексу "Effecton Studio". Cmamucmuчне опрацювання отриманих матеріалів здійснювалось на підставі використання пакету програм багатовимірного статистичного аналізу "Statistica 6.1" за допомогою параметричних методів. Отримані результати засвідчують наявність певних закономірностей. По-перше, слід звернути увагу на погіршання протягом часу перебування в закладів вищої освіти медичного профрілю рівня вираження таких показників функціонального стану вищої нервової діяльності, як швидкість простої і диференційованої зорово-моторної реакції та врівноваженість нервових процесів. По-друге, необхідно визначити стабільні результати в динаміці навчального року, властиві для показників рухливості нервових процесів. По-третє, потрібно підкреслити, що для показників швидкості аудіо-моторної реакції найбільш характерною тенденцією є поступове покращання у динаміці часу перебування в медичних закладах вищої освіти. Таке розмаїття палітри досліджуваних показників ступеня розвитку провідних показників функціонального стану вищої нервової діяльності організму студенток і студентів вимагає на урахування під час здійснення оцінки психофізіологічного статусу досліджуваних осіб та розроблення комплексу діагностичних засобів оцінки процесів формування функціональних можливостей та адаптаційних ресурсів дівчат і юнаків, які здобувають медичну освіту. Ключові слова: студенти, медичні заклади вищої освіти, вища нервова діяльність, функціональний стан, зміни в динаміці навчального року. 


\section{ОСОБЕННОСТИ ИЗМЕНЕНИЙ СО СТОРОНЫ ФУНКЦИОНАЛЬНОГО СОСТОЯНИЯ ВЫСШЕЙ НЕРВНОЙ ДЕЯТЕЛЬНОСТИ СТУДЕНТОВ МЕДИЦИНСКИХ УЧРЕЖДЕНИЙ ВЫСШЕГО ОБРАЗОВАНИЯ В ДИНАМИКЕ УЧЕБНОГО ГОДА Мороз В. М., Макаров С. Ю.}

В структуре важнейших компонентов обеспечения оптимального течения процессов психофизиологической адаптации студенческой молодежи особое место занимает степень психофизиологической готовности организма к эффрективному усвоению профрессионально-значимых навыков и действий. Целью исследования является определение особенностей изменений со стороны ведущих показателей функционального состояния высшей нервной деятельности студентов медицинских высших учебных заведений в динамике учебного года. Определение уровня развития показателей функционального состояния высшей нервной деятельности студентов проводилось на протяжении учебного года с использованием лицензированного компьютерного комплекса "Effecton Studio". Cтатистическая обработка полученных материалов осуществлялась на основе применения пакета программ многомерного статистического анализа "Statistica 6.1" с помощью параметрических методов. Полученные результаты свидетельствуют о наличии определенных закономерностей. Во-первых, следует обратить внимание на ухудшение в течение времени пребывания в высиих учебных заведениях медицинского профиля степени выраженности таких показателей фрунционального состояния высией нервной деятельности, как скорость простой и диффреренцированной зрительно-моторной реакции, а также уравновешенность нервных процессов. Во-вторых, необходимо определить стабильные результаты в динамике учебного года, свойственные для показателей подвижности нервных процессов. В-третьих, необходимо подчеркнуть, что для показателей скорости аудио-моторной реакции наиболее характерной тенденцией является постепенное улучшение в динамике учебного года. Такое разнообразие палитры исследуемых показателей степени развития ведущих показателей функционального состояния высшей нервной деятельности организма студенток и студентов необходимо учитывать в ходе осуществления оценки психофизиологического статуса исследуемых лиц и разработке комплекса диагностических средств оценки процессов формирования функциональных возможностей и адаптационных ресурсов девушек и юношей, получающих медицинское образование.

Ключевые слова: студенты, медицинские учреждения высшего образования, высшая нервная деятельность, функциональное состояние, изменения в динамике учебного года. 